\title{
SOME EXPERIMENTS ON THE NERVOUS PHYSIOLOGY OF DRAGON-FLY LARV E
}

\author{
Ву С. Е. Аввотт, \\ Elgin, Illinois.
}

A number of students of insect physiology have attacked the problem of nervous control. In 1911 Hilton, while making purely morphological studies of certain insects, discovered that the supraœsophageal ganglion consisted largely of sensory elements, whereas the subœsophageal ganglion was rich in motor nerves. But as far as I am aware, the only work of a functional nature that has been done in connection with dragon-fly larvæ is that of Baldus (1924).

During the past summer it was my good fortune to be located in Madison, Wisconsin, where it was possible to obtain and observe many larval specimens of Anax junius and Aeschna umbrosa. I took this opportunity to study the nervous physiology of these insects.

Before considering the experiments, it is necessary to say something about the gross anatomy of the nervous system. Besides the brain and the subœsophageal ganglion, this consists of three thoracic and seven abdominal ganglia. The prothoracic ganglion lies midway between the bases of the first pair of legs. The other thoracic ganglia are very close to each other; both are near the middle pair of legs. The first abdominal ganglion lies in the second segment of the abdomen, and the remaining ganglia lie in the segments following, so that the seventh or terminal ganglion lies in the eighth abdominal division. Each ganglion is connected to the adjoining parts of the body by a pair of lateral nerve fibers. The thoracic ganglia are all large, as also is the terminal abdominal ganglion, but the remaining nerve masses are small. With the exception of the brain, the entire nervous system lies so near the ventral surface of the animal that it is visible through the chitin. The subœsophageal cannot 
be seen from without. It is located near the base of the labium. The brain is visible through the dorsal surface of the head.

To study the function of various parts of this sytem it is only necessary to destroy various parts of it with a needle or a fine knife. Moreover, the vitality of the larvæ is so great that such an operation does not seriously interfere with the vital processes. In all of the experiments, larvæ four to five centimeters long were used.

The prothoracic ganglion of a larva was crushed with a needle. For half an hour after the operation the insect remained motionless. When once it recovered, it could be induced to crawl by gently stroking the dorsal surface of its abdomen. The first pair of legs, limp and powerless, were not used in the process. In the water the larva moved the mildde and rear legs convulsively and irregularly. The mouth-parts moved when touched. Respiratory movements were normal. There was no response to visual stimuli.

The mesothoracic ganglion of a larva was destroyed. After the passage of the shock period the first and last pairs of legs responded to stimulation. The paralysis of the middle pair of legs made crawling practically impossible. Like the preceding larva, this one did not respond to visual stimulation. It also gave little evidence of volition.

The metathoracic ganglia of two different larvæ were destroyed. Both insects gave evidence of shock, disturbance of equilibirum in the water, lack of volition, and inability or disinclination to respond to visual stimuli. Both made some effort to crawl. The rear legs were completely incapable of action and did not respond to stimuli. In the water the first and second pairs of legs moved convulsively. One insect was fairly active; the other seemed almost dead.

The first abdominal ganglion of a larva was destroyed. Although the respiratory movements were somewhat labored and weak after operation, the animal was otherwise quite normal.

The destruction of the third abdominal ganglion of another larva had even less effect than the preceding; the behavior of the insect differed in no way from that of a normal animal. 
Destruction of the fifth abdominal ganglion of another insect resulted in a temporary cessation of respiratory movements.

In the case of a larva with the seventh abdominal or terminal ganglion destroyed the effects were more marked. Not only were the respiratory movements much altered, but the movements of the cloacal spines were completely inhibited.

The last two abdominal ganglia were successively destroyed, and later the entire abdominal part of the nerve cord was removed. Immediately after the destruction of each single ganglion there was a suspension of respiratory action. Later these movements became normal. The removal of all abdominal ganglia led to a complete and permanent cessation of all respiratory movements. There was also a marked decrease in volition, and no responses to visual stimuli.

The subœesophageal ganglion of a larva was destroyed. This inhibited the movements of the mouth-parts; otherwise the insect was normal.

In another case the brain of a larva was cut through in a median plane. The larva tilted its body to the right, and crawled and swam in circles in the same direction. Its reflexes were quite normal.

When the brains of several larvæ were removed through large holes in the heads, and the openings closed with asphaltum, a strong shock effect was produced. After that, responses were normal. The breathing, at first irregular and spasmodic, soon became normal. When resting on a solid surface out of water, the larvæ responded by movements of the abdomen or by crawling. The mouth-parts, and the legs, exclusive of coördinated actions such as crawling, moved spontaneously. Swimming movements were not strong, and probably resulted simply from normal respiratory movements. There was no volition and no response to visual stimuli.

The results of Baldus (1924) with Aeschna cyanea seem to have been similar to those just described. Baldus states that he was able to keep larvæ alive for long period with no heads at all. Most of my specimens did not live over forty-eight hours. But my results agree very well with those of Baldus: namely that the brain of the larva, while important, is not as essential to the 
animal as that of a vertebrate to its possessor. From the above data it is possible to draw the following conclusions:

1. The abdominal ganglia of dragon-fly larvæ control respiratory movements and abdominal movements generally, but this control is so distributed between them that the destruction of one or two does not permanently interfere with respiration.

2. The seventh or terminal abdominal ganglion not only has a greater part of the control of respiratory movements than do the other ganglia, but it also is the seat of the reflex involving the movements of the cloacal spines and probably of the cloacal valve.

3. Each thoracic ganglion controls the actions of the legs attached to its segment. It also has something to do with equilibrium.

4. The subœsophageal ganglion controls the reflexes of the mouth-parts, and without it they cannot act. But the ganglion itself receives no direct stimuli, excepting possibly, those that come through the mouth-parts themselves. Its responses are initiated by stimuli which come through the brain or from other parts of the nervous system.

5. The brain is the sensory, directive, and associative center. Without it responses to visual stimuli cannot take place, and all coördinated spontaneous movements are inhibited. It also serves in some way as an organ of balance and orientation. The mouth-parts cannot act selectively without the brain. In short, the real brain of the insect consists of both the sub and the supraœsophageal ganglia. The former is the motor, the latter the sensory mechanism.

Baldus, $K$.

\section{Literature}

1924. Untersuchungen über Bau und Funktion des Gehirnes der Larve und Imago von Libellen. Zeits. Wiss. Zool., vol. 121.

Hilton, W. A.

1911. Some Remarks on the Motor and Sensory Tracts of Insects Journ. Comp. Neur. XXI, No. 4. 

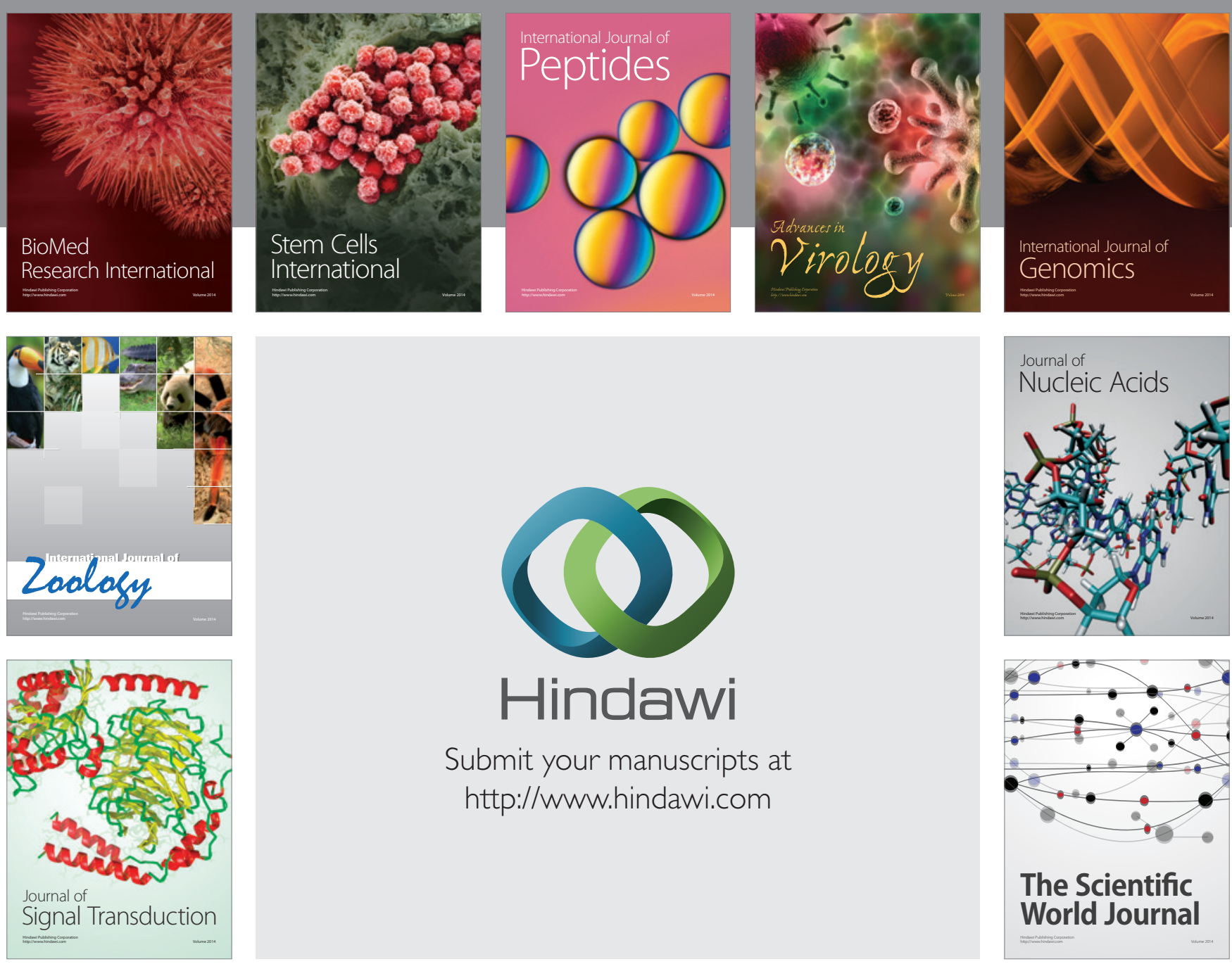

Submit your manuscripts at

http://www.hindawi.com
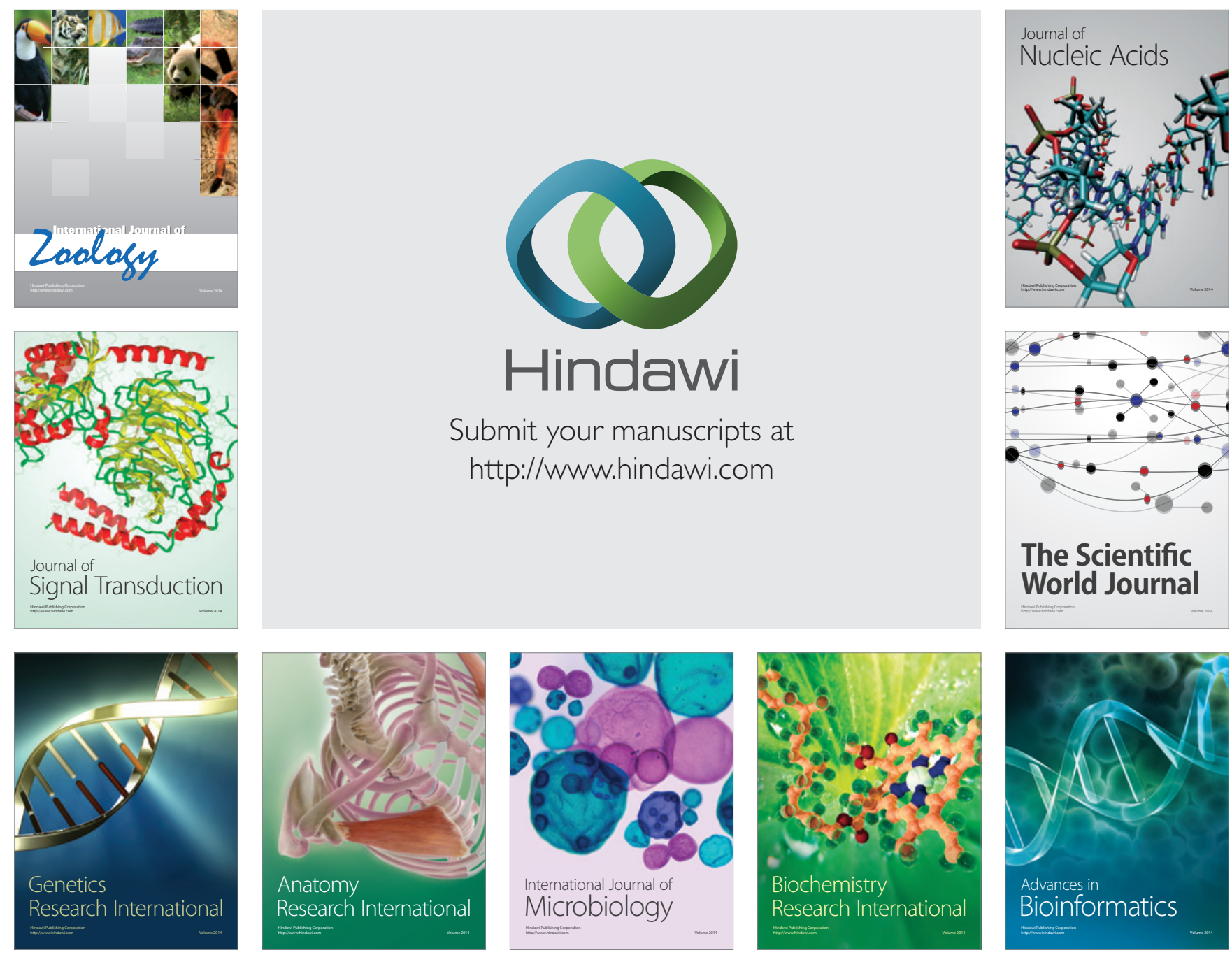

The Scientific World Journal
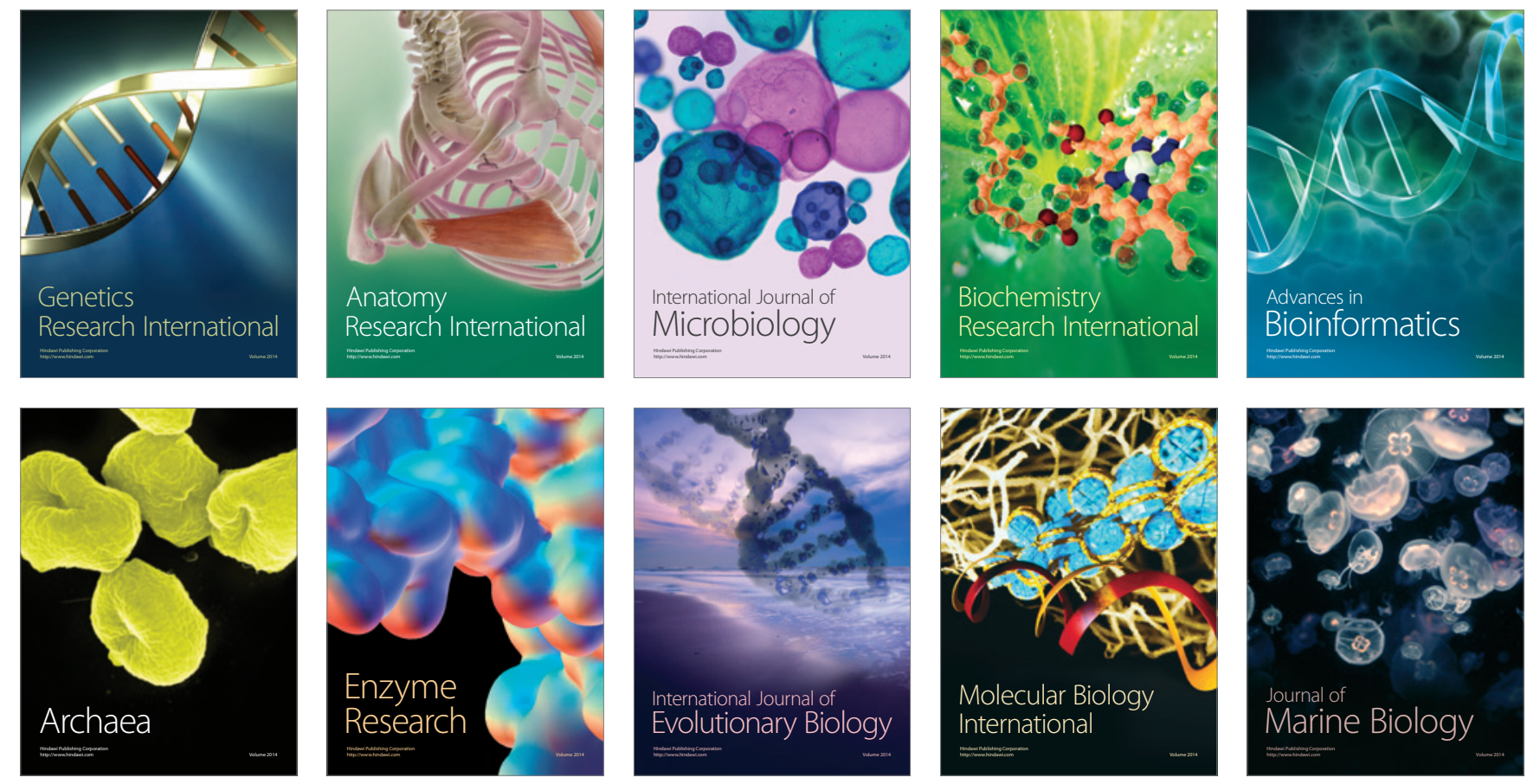